\title{
Deliberatywna fuzja międzyrządowa - (post-)kryzysowe podejście w badaniach integracji europejskiej
}

\section{Wprowadzenie}

Globalny kryzys ekonomiczny zapoczątkowany w 2008 roku spowodował pojawienie się nowych zjawisk w szczególnym systemie politycznym, jakim jest Unia Europejska. System ten wciąż oparty jest na współpracy państw członkowskich i aktorów ponadnarodowych (Pietraś, 2005, s. 37), ale podlega coraz głębszym zmianom strukturalnym i funkcjonalnym. Wynikiem narastających sprzeczności interesów państw członkowskich staje się postępująca dezintegracja Unii, która prowadzi do dalszego osłabienia aktorów niepaństwowych. Rozwiązaniem do pewnego stopnia alternatywnym może stać się przedmiotowe i podmiotowe zróżnicowanie integracji.

Integracja europejska staje się zatem zjawiskiem na tyle skomplikowanym, że wymusza tworzenie nowych podejść teoretycznych umożliwiających jej badanie. Jedną ze ścieżek może być tu koniunkcja koncepcji wcześniejszych (Czachór, 2013). Celem niniejszego artykułu jest przedstawienie nowego podejścia bazującego na połączeniu liberalnej teorii międzyrządowej, teorii fuzji i teorii deliberatywnego supranacjonalizmu. Główną myślą jest stwierdzenie, że żadna z istniejących koncepcji teoretycznych nie jest w stanie wyjaśnić istoty procesów integracyjnych w ramach Unii Europejskiej. W pierwszej części przedstawiono podstawowe założenia wskazanych teorii (traktowanych jako koncepcje wyjściowe), a w części drugiej przeanalizowano główne cechy Unii Europejskiej w czasie kryzysu i zaprezentowano oparte na tej analizie nowe podejście koniunktywne (deliberatywną fuzję międzyrządową). Wydaje się, że zaproponowana nowa koncepcja wykazuje przydatność nie tylko w sytuacji kryzysowej, ale może oferować odpowiednie instrumenty analizy integracji w ramach UE także w okresie pokryzysowym.

\section{Koncepcje wyjściowe}

Pomimo istnienia wielu klasyfikacji teorii integracji europejskiej do najważniejszych współczesnych koncepcji zaliczyć należy: federalizm, neofunkcjonalizm, liberalną teorię międzyrządową, podejścia oparte na teorii rządzenia, teorię sieciową, instytucjonalizm, konstruktywizm, podejścia dyskursywne, podejścia oparte na teorii płci, teorię normatywną oraz krytyczne teorie ekonomiczne (Wiener, Diez, 2009). W niniejszym artykule zaproponowano przeanalizowanie tylko trzech koncepcji wyjś- 
ciowych, przy czym dobór ten ma charakter nieprzypadkowy. Jego celem jest bowiem późniejsze połączenie koncepcji teoretycznych różniących się od siebie nie tylko charakterystyką procesów integracyjnych, lecz również pozycją w hierarchii teorii. O ile bowiem liberalna teoria międzyrządowa traktowana jest jako koncepcja wyjaśniająca ogół procesów integracyjnych, o tyle teoria fuzji jest teorią średniego rzędu wyjaśniającą przede wszystkim funkcjonowanie administracji, a teoria deliberatywnego supranacjonalizmu jest podejściem służącym wyjaśnieniu procesów prawotwórczych. Należy dodać, że trzy częściowo odmienne pojęcia (teoria, podejście, koncepcja) traktowane są w niniejszym artykule jako synonimy. Zabieg ten ma na celu unikanie nierelewantnych z punktu widzenia pracy debat terminologicznych (Skarzyński, 2012).

Pierwszą wyjściową koncepcję teoretyczną stanowi liberalna teoria międzyrządowa. Opiera się ona na czterech założeniach (Finke, 2009, s. 466-473). Po pierwsze, aktorzy ponadnarodowi nie mają dużego wpływu na wynik negocjacji międzypaństwowych w ramach Unii Europejskiej. Po drugie, najważniejszą rolę w procesach decyzyjnych w UE odgrywają rządy największych państw członkowskich. Po trzecie, ograniczenia proceduralne nie mają szczególnego znaczenia, gdy negocjowane są ważne interesy państwowe. Wprowadzanie istotnych zmian do systemu politycznego UE, w tym poważnych zmian traktatowych, nie jest łatwe i musi odzwierciedlać interesy głównych aktorów narodowych. Po czwarte, negocjacje międzyrządowe w UE toczą się w warunkach ciaggłego poszukiwania równowagi systemowej. Cechą systemu jest jednak ciagła nierównowaga, która zmusza aktorów państwowych do stałej aktywności.

W modelu tym wyróżnia się trzy fazy procesu decyzyjnego: a) formację preferencji w zakresie polityki zewnętrznej; b) przetargi międzyrządowe; c) delegację instytucjonalną. W kontekście wyboru preferencji podkreśla się rolę interesów mikroekonomicznych, które są następnie uzupełniane motywacjami geopolitycznymi i ideologicznymi. Podczas przetargów między uczestnikami międzynarodowych procesów decyzyjnych pod uwagę brane są jedno- i wielostronne alternatywy dla konkretnych porozumień, w tym rozwiązania pakietowe, możliwości wyłączenia z procesu decyzyjnego oraz całkowita rezygnacja z negocjacji. Wpływ aktorów ponadnarodowych jest $\mathrm{w}$ tej sytuacji ograniczony i pojawia się głównie wtedy, gdy posiadają oni silnych sojuszników narodowych. Delegacja instytucjonalna oznacza w pewnym stopniu wspólne wykonywanie (pooling) suwerenności. Pojawia się ona tam, gdzie rządy poszukują wiarygodnych zobowiązań w warunkach niepewności, szczególnie w razie konieczności znalezienia wspólnych rozwiązań podatnych na niepełną implementację (Moravcsik, 1995, s. 612).

Liberalna teoria międzyrządowa jest w rzeczywistości zreformowaną wersją podejścia realistycznego. W przeciwieństwie do klasycznego realizmu brana jest tu jednak pod uwagę zasadnicza rola polityki wewnętrznej państwa w kształtowaniu jego zachowań międzynarodowych. Państwa odpowiadają na interesy wewnętrzne, a aktywność polityków narodowych ucieleśnia interes państwa i odzwierciedla wewnętrzne preferencje polityczne. Cele polityki zagranicznej rządów narodowych są wynikiem zróżnicowanych odpowiedzi na presję wewnętrznych grup społecznych (Wincott, 1995, s. 600).

Według liberalnej teorii międzyrządowej główne decyzje w Unii Europejskiej nie są podejmowane w warunkach anarchii, lecz w ramach akceptacji wcześniejszych po- 
rozumień i społecznej adaptacji do nich. Wcześniejsze porozumienia stanowią status quo, na podstawie którego aktorzy społeczni i rządy kalkulują swoje preferencje i alternatywy. W tym kontekście należy podkreślić wpływ urzędników ponadnarodowych wykonujących wiele funkcji delegowanych przez rządy (szczególnie w warunkach niepełnej informacji i niepewności). Każdy przetarg jest uwarunkowany wcześniejszymi przetargami i wpływa na przyszłe negocjacje. Decyzje międzyrządowe nie muszą przy tym wcale opierać się jedynie na najmniejszym wspólnym mianowniku (Moravcsik, 1995, s. 612).

Krytycy liberalnej teorii międzyrządowej zarzucają jej niedojrzałość. Wynika ona przede wszystkim z nieodporności na argumenty empiryczne, która powoduje, że koncepcja ta powinna być traktowana w ścisłym ujęciu nie jako teoria, lecz podejście (approach) ugruntowane pewnym zbiorem uwarunkowań metodologicznych (Wincott, 1995, s. 600). Także zwolennicy liberalnej teorii międzyrządowej przyznają, że nie jest ona w pełni adekwatna do wszystkich wymiarów funkcjonowania UE. Stanowi jednak fundamentalny punkt wyjścia dla każdej generalizacji w obszarze regionalnej integracji międzynarodowej, bazując na dynamicznym połączeniu współczesnych teorii ekonomiczno-politycznych, teorii negocjacji i teorii reżimów. W tej sytuacji koncepcja ta wykazuje dużą skuteczność nie tylko w kontekście badania decyzji podejmowanych na wysokim szczeblu, lecz także niektórych decyzji rutynowych (Moravcsik, 1995, s. 611-613; Moravcsik, Schimmelfennig, 2009, s. 74).

Według innych krytyków liberalna teoria międzyrządowa posiada cztery główne wady. Pierwszą z nich jest traktowanie państw członkowskich jako unitarnych aktorów negocjacji międzynarodowych. Nie jest tu zatem brane pod uwagę zróżnicowanie wewnętrzne (ustrojowe) poszczególnych państw, a także niedoceniana jest autonomia rządów narodowych wobec wewnątrzpaństwowych grup społecznych. Drugą wadą jest podkreślanie roli dużych państw członkowskich w negocjacjach i możliwości, jakie dają im rozwiązania polegające na stosowaniu wypłat ubocznych i symbolicznych koncesji wobec innych państw. Badania empiryczne kolejnych reform traktatowych nie potwierdzają dominacji dużych państw. Trzecią wadę stanowi ignorowanie roli procedur decyzyjnych w UE i uznawanie całkowicie swobodnych przetargów za dominujący model podejmowania decyzji. Pogłębianie integracji doprowadziło jednak do przeniesienia akcentów z koordynacji polityki na rzecz problemów redystrybucyjnych, co prowadzi do podniesienia kosztów transakcyjnych. Po czwarte, w omawianej teorii zakłada się idealny dostęp do informacji, czyli występującą u wszystkich uczestników procesu negocjacyjnego znajomość zasad proceduralnych i preferencji pozostałych aktorów. W tym kontekście należy jednak podkreślić wzrost liczby państw członkowskich uniemożliwiający zaistnienie takiej sytuacji (Finke, 2009, s. 468-472; Strzyczkowski, 2012, s. 98-116).

Drugą wyjściową koncepcję teoretyczną stanowi teoria fuzji. Według niej Unia Europejska skonstruowana jest w taki sposób, aby - posiadając własne cele - nie sprzeciwiać się celom państw członkowskich. Zauważyć tu można zatem zarówno elementy międzyrządowe, jak i ponadnarodowe czy federalistyczne. W ujęciu teorii fuzji kolejne reformy traktatowe wzmacniają wszystkie główne instytucje Unii, co nie pozwala na jednoznaczną ocenę kierunku reform. Sprzeczności międzyinstytucjonalne i wynikający z nich brak transparencji i rozmycie odpowiedzialności są wbudowane w system polityczny UE, który łączy w sobie elementy międzyrządowe i federalistyczne. 
Rozwój systemu politycznego Unii Europejskiej przyjmuje postać „drabiny fuzyjnej” (fusion ladder). Kolejne reformy traktatowe polegają bowiem zwykle na wzmocnieniu dwóch tendencji: przechodzenia do rozwiązań ponadnarodowych i zwiększania liczby kompetencji Unii. Stałą cechą UE jest jednak także dążenie do znalezienia punktu równowagi w niezrównoważonym środowisku wewnętrznym. Praktyka konstytucyjna Unii prowadzi do coraz silniejszej fuzji instytucjonalnej pozbawionej jasnego podziału kompetencji. Efektem jest zazwyczaj przejście do nowego poziomu integracji (Wessels, 2005, s. 13-33).

Przedstawiciele teorii fuzji kładą szczególny nacisk na współpracę administracji państw członkowskich oraz administracji ponadnarodowej. Wyróżniają dwa modele fuzji administracyjnej. Pierwszy z nich polega na tworzeniu jednolitej europejskiej „megaadministracji”. Według tej wizji pojęcie fuzji właściwie opisuje aktualny stan administracji europejskiej opartej na ,nowym podzielonym systemie rządzenia” i łączeniu się systemów politycznych. Drugi model fuzji kładzie nacisk na zróżnicowanie porządków administracyjnych i warunkowość procesu fuzji zależnego od tych porządków. Ilustracją tego modelu jest udział państwowych instytucji wykonawczych i urzędników narodowych w podejmowaniu decyzji w UE. Fuzja ma zatem charakter zróżnicowany, segmentowy i sektorowy. Podstawowe znaczenie ma tu zatem różnorodność sposobów zorganizowania porząqków wykonawczych na różnych poziomach rządzenia, a instytucje UE mają wpływ na hierarchicznie zorganizowane procesy decyzyjne wewnątrz państw członkowskich (Trondal, 2010, s. 253-255).

W kontekście fuzji w obszarze administracyjnym należy podkreślić, że w Unii Europejskiej powstaje wieloskładnikowy „europejski porządek wykonawczy” charakteryzujący się współwystępowaniem złożonych dynamik decyzyjnych, przy czym wewnątrzpaństwowa część władzy wykonawczej jest stale penetrowana przez te dynamiki. Porządki wykonawcze na różnych poziomach nie istnieją równolegle, lecz są połączone ( fused) i zintegrowane. Państwa członkowskie dążą do zwiększenia wpływu na działalność biurokracji międzynarodowej poprzez sterowanie nią w pożądanych przez siebie kierunkach oraz w celu minimalizacji wpływu innych państw. Nawet w instytucjach ponadnarodowych podstawowe znaczenie ma dynamika sektorowa, która stanowi punkt wyjścia dla dynamiki ponadnarodowej i epistemicznej (Curtin, Egeberg, 2008, s. 648-651; Trondal, 2010, s. 250-253).

W ogólniejszym ujęciu najważniejsze elementy fuzyjne występują w następujących zasadach funkcjonowania Unii: a) zasadzie przyznania, według której państwa członkowskie decydują o przekazaniu niektórych kompetencji na poziom Unii; b) zasadzie pomocniczości, która nakłada na państwa członkowskie główną odpowiedzialność za obowiązujące $w$ nich regulacje prawne i ogranicza aktywność prawotwórczą UE; c) zasadzie proporcjonalności wymagającej od Unii działania zgodnego z jej celami i postulującej deregulację. Podział kompetencji między Unię a państwa członkowskie wykazuje w obszarze kompetencji dzielonych praktyczną tendencję do wzmacniania uprawnień Unii, która nie jest jednak przekształcana w „superpaństwo”. Nadal posiada ona bowiem niewielki budżet i wykazuje niewielką aktywność w sferze współpracy militarnej (Wessels, 2005, s. 17-18).

Trzecią koncepcją wyjściową jest teoria deliberatywnego supranacjonalizmu. Według tego podejścia Unia Europejska stanowi system wielopoziomowy cechujący się 
procesami polityzacji i instytucjonalizacji, których legitymizacja powinna być mierzona jakością deliberacyjną procesów decyzyjnych. Jakość ta musi być gwarantowana za pomocą reguł prawnych i wynikać z połączenia organów decyzyjnych państwa narodowego i Unii (Joerges, 2002, s. 139). Teoria ta opiera się na podkreśleniu wagi konfliktu systemów prawnych i oscyluje wokół trzech przesłanek: a) istnienia funkcjonalnych i normatywnych przyczyn przekształcania się autarkicznego państwa konstytucyjnego; b) filozofii europejskiego prawa konstytucyjnego operacjonalizującej regulacyjny ideał ,jedności w różnorodności”; c) zakorzenienia europejskiej teorii konstytucyjnej w analizach empirycznych i rozwiązywaniu konkretnych konfliktów ponadnarodowych (Menendez, 2011, s. 1-4).

W innym ujęciu teoria ta opiera się na przyjęciu dwóch tez (Joerges, 2002, s. 139-142). Po pierwsze, Unia Europejska nie stała się „rynkiem bez państwa”, a państwa członkowskie nie przekształciły się w ,państwa bez rynku”. Zasada wzajemnego uznania rozwiązań prawnych zastąpiła bardziej skomplikowane zasady prawnomiędzynarodowe regulujące konflikty prawne. Prawo UE nie pełni tylko funkcji strażnika przestrzegania zasady swobody konkurencji, lecz także staje się kryterium i instrumentem deregulacji wewnątrz państw członkowskich. Po drugie, Unia Europejska nie przekształciła się w „państwo regulacyjne”, w którym rynek wewnętrzny (oparty na ,re-regulacji” i modernizacji) kierowany jest decyzjami instytucji niewiększościowych. Powstały system oferuje raczej perspektywę konstytucyjną o szerszym znaczeniu.

W szerokiej perspektywie Unia Europejska musi być postrzegana jako dojrzały system polityczny, który podlega wymogom podobnym do polityki narodowej. Korzenie tej koncepcji odnaleźć można w przeświadczeniu, że polityka europejska nie polega jedynie na strategicznych interakcjach $w$ ramach formalnych instytucji. Badania empiryczne wskazują bowiem na duże znaczenie dyskursywnych modeli interakcji. Całą koncepcję można nazwać podejściem normatywnym sui generis dopasowanym do sui generis struktury Unii (Neyer, 2006, s. 779-780).

Deliberatywny supranacjonalizm jest według jego zwolenników rozwiniętą teorią integracji. Oferuje on bowiem, po pierwsze, oryginalne wyjaśnienie legitymizacji prawa UE. Główną wartością normatywną tego prawa jest stanowienie zespołu norm organizujących wspólistnienie narodowych porządków prawnych. Wspótistnienie to stanowi remedium dla deficytu demokratycznego wynikającego z charakteru Unii jako systemu suwerennych państw narodowych. Prawo UE jako konfliktowy porządek prawny nie musi posiadać własnej legitymizacji demokratycznej. Po drugie, deliberatywny supranacjonalizm nadaje zasadzie pierwszeństwa prawa UE charakter operacyjny. Nie traktuje on tej zasady jako automatycznej i bezwarunkowej, lecz postrzega ją raczej jako instrument służący zorganizowaniu efektywnej koegzystencji narodowych porząaków prawnych. Po trzecie, percepcja prawa UE w kategoriach konfliktu systemów prawnych przyczynia się do definiowania go jako stabilizatora europejskiego porządku politycznego. Transnarodowa percepcja Unii pozwala ograniczyć strukturalny deficyt demokratyczny państw członkowskich bez podważania trzonu legitymizacji demokratycznej państwa narodowego: poprzez wzajemne uznanie i współpracę administracyjną demokracja na poziomie narodowym jest transferowana na poziom europejski (Menendez, 2011, s. 9-10). 
Według przedstawicieli teorii deliberatywnego supranacjonalizmu problem funkcjonowania Unii Europejskiej nie może być rozwiązany przez prostą instytucjonalizację technokracji ponadnarodowej. Prawo UE nie może bowiem imitować modeli narodowych, a raczej powinno poszukiwać ich funkcjonalnych ekwiwalentów. Pomimo niedociagnięć w obszarze transparencji system ponadnarodowy gwarantuje narodowo zorganizowanej opinii publicznej wiele możliwości wpływu na decyzje podejmowane na poziomie Unii. W tym ujęciu można mówić o powstaniu transnarodowego forum deliberacyjnego (Joerges, 2002, s. 150-151).

Deliberatywny supranacjonalizm posiada trzy zasadnicze cechy odróżniające go od innych teorii (Menendez, 2011, s. 4-5). Po pierwsze, jednym z zadań, przed jakim stoją zwolennicy tej koncepcji, jest konieczność przeanalizowania problemu różnic i podobieństw między analogicznymi sytuacjami prawnymi pojawiającymi się na poziomie narodowym i ponadnarodowym. Po drugie, definiowanie prawa innych państw jako prawa obowiązującego (a nie tylko przyjęcie do wiadomości tego faktu) prowadzi do konieczności transformacji instytucji narodowych w kierunku kontrolowania interesów szerszych od interesów obywateli danego państwa. Po trzecie, uświadomienie konieczności procesu otwarcia systemu prawnego państwa na systemy innych państw prowadzi do powstania mechanizmów umożliwiających prowadzenie dyskusji na temat wspólnych standardów normatywnych.

\section{(Post-)kryzysowa koncepcja koniunktywna}

Długotrwały i wielopłaszczyznowy kryzys Unii Europejskiej stał się powodem poszukiwania nie tylko nowych rozwiązań politycznych i ekonomicznych, lecz również nowych podejść teoretycznych. Punktem wyjścia analizy musi być jednak zawsze diagnoza sytuacji bieżącej (Tosiek, 2014, s. 429-432). Przyjmując założenie o podstawowym wpływie państw na procesy decyzyjne zachodzące w Unii Europejskiej, należy zatem zastosować oferowany przez podejście międzyrządowe schemat analizowania kryzysowej sytuacji decyzyjnej. Obejmuje on trzy płaszczyzny: preferencje, negocjacje oraz instytucje (Moravcsik, Schimmelfennig, 2009, s. 69).

Preferencje decydentów kształtują się podczas kryzysu pod wpływem czterech zjawisk. Po pierwsze, obok uwarunkowań ekonomicznych dużą rolę odgrywają prawne komponenty systemu decyzyjnego. Nowym zjawiskiem jest nagminne uzupełnianie rozwiązań traktatowych aktami prawnymi nienależącymi do acquis (np. pakt fiskalny, unia bankowa). Po drugie, poszczególni decydenci w różny sposób podchodzą do problemów ekonomicznych. Ogólny schemat obejmuje recepty oparte na zmniejszaniu deficytów budżetowych i ograniczaniu wydatków publicznych lub rozwiązania oparte na stymulowaniu wzrostu gospodarczego i aktywnej polityce społecznej (Scicluna, 2012, s. 500). Po trzecie, rządy największych państw członkowskich, wykazują tendencję do projektowania własnych interesów narodowych na interesy europejskie. Przykładem są choćby niektóre rozwiązania ujęte w pakcie fiskalnym, w tym przede wszystkim zachęta do konstytucjonalizacji wymogów makroekonomicznych (Cichocki, 2012, s. 3-5). Po czwarte, kryzys nie spowodował umocnienia preferencji na rzecz federalizacji Unii, a debata o strategicznych celach integracji europejskiej została 
osłabiona. Główny punkt zainteresowania obywateli państw członkowskich i elit politycznych stanowią bowiem problemy gospodarcze, które nie mogą być rozwiązane bez długotrwałych negocjacji międzyrządowych (Scicluna, 2012, s. 499-501).

Negocjacje wewnątrz systemu decyzyjnego Unii toczą się w warunkach kształtowanych trzema zjawiskami. Po pierwsze, wskutek sprzecznych interesów różnych decydentów pojawiła się realna perspektywa rozpadu Unii Europejskiej lub przynajmniej strefy euro. Lepszy dostęp do informacji o preferencjach innych decydentów może prowadzić do manipulacji ukierunkowanej na maksymalizację realizacji własnych interesów (Moravcsik, Schimmelfennig, s. 70-71). Po drugie, pojawiła się niepewność dotycząca kierunków rozwoju Unii Europejskiej. Kryzys uświadomił decydentom, że Unia nie jest projektem wymagającym ciagłego rozwoju. Pojawiły się zatem żądania powrotu części uprawnień przekazanych na poziom Unii do państw (Scicluna, 2012, s. 498-500). Po trzecie, realnym mechanizmem rozwiązywania problemów kryzysowych stała się współpraca ściśle międzyrządowa, która skutkuje jakościowym osłabieniem ponadnarodowych instytucji UE. Całkowicie nowym zjawiskiem jest silna ingerencja większych partnerów w politykę wewnętrzną niestabilnych państw.

Kryzys spowodował także pojawienie się czterech nowych zjawisk w systemie instytucjonalnym Unii (Kunstein, Wessels, 2011, s. 309). Po pierwsze, postanowiono zawrzeć pakt fiskalny, który nie obejmuje wszystkich państw członkowskich. Niejasna jest jego konstrukcja prawna, sposób wejścia w życie i obowiązywania, a także regulacja obowiązków państw będących jego stronami. Po drugie, nową konstrukcjąjest tzw. sześciopak przewidujący silniejsze powiązanie deficytu budżetowego ze wzrostem gospodarczym. Potencjalnie wzmocniono w nim kontrolną rolę Komisji Europejskiej, ale najważniejsze decyzje pozostawiono w gestii Rady. Po trzecie, powołano do życia kolejne instrumenty instytucjonalne w finalnej postaci Europejskiego Mechanizmu Stabilności. Instrumenty te mają służyć bezpośrednim interwencjom finansowym w przypadku pojawienia się niestabilnej sytuacji finansowej w konkretnych państwach członkowskich. Po czwarte, niektóre państwa członkowskie przystapiły do Paktu Euro-Plus mającego na celu wzrost konkurencyjności i konwergencji pod ogólną kontrolą Komisji Europejskiej, która nie dysponuje jednak w tym przypadku możliwością nakładania sankcji.

Z punktu widzenia interakcji międzyrządowych państwa mogą wybrać jedną z trzech opcji zachowania się w kryzysowym środowisku międzynarodowym (Strzyczkowski, 2012, s. 90). Po pierwsze, rządy mogą wykazywać tendencję do prowadzenia polityki jednostronnej i niechęć do porozumiewania się z innymi decydentami. W przypadku UE opcję tę w kontekście paktu fiskalnego wybrały Zjednoczone Królestwo i Czechy. Wydaje się, że praktyka ta nie znajdzie jednak przełożenia na wszystkie sfery funkcjonowania, ponieważ doprowadziłaby do całkowitej dezintegracji UE. Po drugie, państwa mogą wchodzić w koalicje tylko z niektórymi partnerami i tworzyć różne kręgi integracyjne. W kontekście sytuacji gospodarczej przykładem może być wspólne działanie aktorów reprezentujących podejście oparte na restrykcyjnej polityce fiskalnej. Po trzecie, państwa mogą dążyć do pełnego kompromisu wszystkich partnerów. Tego typu podejście - z uwagi na dużą liczbę partnerów - wydaje się obecnie mało prawdopodobne (Tosiek, 2014, s. 435).

Nietrudno zauważyć, że wspólną cechą wskazanych zjawisk jest ukierunkowanie rozwoju Unii Europejskiej na przedmiotowe i podmiotowe zróżnicowanie procesów 
integracyjnych. W ujęciu teoretycznym podejście takie można zaobserwować z coraz większym natężeniem już w pracach analizujących strukturę i funkcjonowanie UE po rozszerzeniu z 2004 roku. Kryzys pogłębił jedynie tę tendencję. Obok koncepcji tradycyjnych (Kölliker, 2001) pojawiły się cztery bardziej atrakcyjne podejścia analityczne. Po pierwsze, proponuje się koncepcję zróżnicowania anarchicznego. Opiera się ona na nieprzewidywalnym rozwoju systemu politycznego bazującym na rozwiązaniach ad hoc. Wariantami tego podejścia są: a) dalsze istnienie Unii na zasadzie status quo; b) dominacja procesów typu spill-over; c) pojawienie się silnych procesów typu spill-back. Rozwiązaniem przeciwstawnym mogłoby być zaś świadome zreformowanie Unii (Sudbery, 2008, s. 13). Po drugie, jednym z rozwiązań może być koncepcja rządzenia plurilateralnego. Opiera się ona na postrzeganiu Unii jako zjawiska politycznego cechującego się interpenetracją różnych typów jednostek politycznych i związanych z nimi lojalności, co w praktyce ma oznaczać wzmocnienie deliberacji i bardziej elastyczna, zdecentralizowaną i łagodną formę rządzenia (Zielonka, 2007). Po trzecie, nowym ujęciem analitycznym może być postrzeganie Unii Europejskiej jako struktury „wielowarstwowej” (metafora European Onion). W takiej sytuacji rządzenie odbywa się w warunkach współpracy i rywalizacji jednostek podzielonych nie tylko sektorowo (merytorycznie), ale także w ramach wielu podgrup państw członkowskich (de Neve, 2007). Po czwarte, prawdopodobnym kierunkiem rozwoju Unii Europejskiej jest nieprzestrzeganie reguł (non-compliance) przez państwa członkowskie niezainteresowane niektórymi rozwiązaniami przyjętymi na poziomie Unii. Ujęcie to może stanowić alternatywę dla integracji zróżnicowanej (Holzinger, Schimmelfennig, 2012, s. 303).

Biorąc pod uwagę aktualną tendencję występującą zarówno w debatach teoretycznych, jak i wśród praktyków, należy zgodzić się z podstawowym założeniem polegającym na postrzeganiu Unii Europejskiej jako organizacji cechującej się coraz większym zróżnicowaniem wewnętrznym. Wydaje się jednak, że w prezentowanych analizach brakuje spójnego podejścia teoretycznego odnoszącego się do istoty procesów integracyjnych w ramach Unii. W ujęciu systemowym istota ta zawiera w sobie dwa podstawowe składniki: a) materialny - dotyczący przedmiotu decydowania politycznego; b) formalny - dotyczący przebiegu procesów decydowania politycznego (Pietraś, 1998). Pozytywną rolę mogłaby tu odegrać próba stworzenia podejścia analitycznego bazującego na połączeniu najważniejszych elementów trzech przedstawionych powyżej koncepcji teoretycznych. Efektem byłoby wówczas zaproponowanie nowego podejścia do badań integracji europejskiej: deliberatywnej fuzji międzyrząawej. Koncepcja ta posiadałaby dziewięć podstawowych cech (po trzy wynikające z każdej z teorii wyjściowych).

Do głównych elementów proponowanego podejścia należy zaliczyć trojakie postrzeganie deliberacji (Neyer, 2006, s. 781-788). Po pierwsze, w rozumieniu normatywnym deliberacja bazuje na uznaniu heterogeniczności Unii za normatywną podstawę procesów decyzyjnych, gdzie w centrum uwagi stawiany jest brak zgody (disagreement) przyczyniający się do trwałego procesu konstytucjonalizacji politycznej ukierunkowanej na rozpoznawanie, respektowanie i reprezentowanie wartości, opinii i żywotnych interesów uczestników procesu decyzyjnego. Po drugie, w rozumieniu racjonalistycznym deliberacja opiera się na traktowaniu własnego interesu aktorów politycznych jako głównego źródła ich motywacji, gdzie konflikty interesów są rozwiązywane także poprzez 
przetargi i głosowania. Polityka jest tu pochodną interakcji aktorów zbiorowych reprezentujących „kombinowany” interes będący produktem wcześniejszego decydowania kolektywnego wewnątrz państw. Po trzecie, w rozumieniu funkcjonalnym deliberacja bazuje na dążeniu do osiagnięciu celu w postaci efektywnego i legitymizowanego rządzenia Unią Europejska, przy czym każda decyzja będąca wynikiem deliberacji opiera się na zastosowaniu procedur zorientowanych na konwergencję lub co najmniej na wiarygodne uzasadnienie odrzucenia interesów niektórych uczestników procesu decyzyjnego.

Proponowane podejście zawiera także trzy elementy właściwe dla teorii fuzji. Po pierwsze, podstawową cechą Unii jest „,wielopoziomowy konstytucjonalizm” oparty na komplementarności polityk publicznych prowadzonych na różnych poziomach, gdzie celem głównym jest osiaganie pierwotnych celów poszczególnych państw, a fundamentalnym wzorcem konstrukcji Unii jest konkurencja różnych trendów w ramach wspólnej architektury konstytucyjnej (Wessels, 2005, s. 13-14). Po drugie, występujący wewnątrz państw członkowskich proces europeizacji nie oznacza powstania jednolitego modelu polityczno-instytucjonalnego, lecz przejawia się koniecznością współpracy między instytucjami/organami UE i instytucjami państw członkowskich (Wessels, 1998, s. 227-229). Po trzecie, stanowiące podstawę funkcjonowania Unii zasady przyznania, pomocniczości i proporcjonalności postrzegać należy jako elementy konstrukcyjne ukierunkowane na ograniczanie procesów typu spill-over. Coraz większe znaczenie odgrywa także zasada elastyczności umożliwiająca tworzenie grup państw dążących do bliższej współpracy (Wessels, 2005, s. 17-18).

Istotą proponowanego podejścia pozostałoby jednak uznanie Unii Europejskiej za organizację o charakterze przede wszystkim międzyrządowym. Dużą przydatność eksplanacyjną wykazują bowiem trzy elementy wywodzące się z liberalnej teorii międzyrządowej. Po pierwsze, w okresie kryzysowym aktorzy ponadnarodowi wywieraja niewielki wpływ na wynik negocjacji prowadzonych między państwami członkowskimi. Cechą główną powstającego systemu jest zatem zdecydowana przewaga decyzyjna aktorów rządowych i międzyrządowych w warunkach ciagłego poszukiwania stanu równowagi systemowej (Finke, 2009, s. 466-473). Po drugie, zasadniczą rolę w kształtowaniu preferencji państw odgrywa ich polityka wewnętrzna, a aktywność polityków narodowych odzwierciedla stanowiska polityczne relewantnych aktorów wewnętrznych. Ograniczone znaczenie ma tu także powiązanie aktorów narodowych z otoczeniem transnarodowym (Wincott, 1995, s. 600). Po trzecie, rządy państw członkowskich cechuje pogłębiona autonomia w stosunku do innych aktorów wewnątrzkrajowych. Wyraża się ona między innymi w wykorzystywaniu członkostwa w UE do wywierania nacisku na niektóre wewnątrzkrajowe grupy społeczne i zwiększania własnej swobody decyzyjnej. W skrajnych przypadkach może to oznaczać daleko idącą autonomię rządów wobec całej opinii publicznej (Finke, 2009, s. 468-472; Strzyczkowski, 2012, s. 98).

\section{Podsumowanie}

Żadne z aktualnie istniejących podejść teoretycznych w badaniach integracji europejskiej nie oferuje instrumentów służących pełnemu wyjaśnieniu istoty procesów za- 
chodzących w Unii Europejskiej. Konieczne jest zatem łączenie różnych koncepcji i wyjaśnianie poszczególnych zjawisk w sposób zróżnicowany przedmiotowo i podmiotowo. Ujęcie takie jest szczególnie przydatne w przypadku analizy struktury i funkcjonowania UE w czasie kryzysu.

Zaproponowane w niniejszym artykule podejście zwane deliberatywną fuzją międzyrządową jest wynikiem połączenia trzech teorii różnego rzędu: liberalnej teorii międzyrządowej (koncepcji ogólnej), teorii fuzji (wyjaśniającej współpracę administracyjna) oraz teorii deliberatywnego supranacjonalizmu (służącej wyjaśnianiu procesów prawotwórczych). Wydaje się jednak, że analiza podstawowych zjawisk i procesów zachodzących obecnie w Unii Europejskiej pozwala traktować wszystkie trzy koncepcje teoretyczne - niezależnie od formalnych różnic hierarchicznych - jako teorie o charakterze ogólnym. Twierdzenie to zyskuje na znaczeniu w przypadku próby stworzenia podejścia koniunktywnego.

Należy domniemywać, że kryzysowe zmiany w systemie politycznym UE mają charakter trwały, ponieważ odnoszą się nie tylko do form współpracy między państwami członkowskimi (i aktorami ponadnarodowymi), ale także do przedmiotu tej współpracy. Zaproponowane nowe podejście teoretyczne powinno zatem wykazać przydatność nie tylko w sytuacji kryzysowej, ale także w okresie pokryzysowym. Na pewno zaś koncepcja deliberatywnej fuzji międzyrządowej może stanowić punkt wyjścia do dalszych rozważań teoretycznych dotyczących funkcjonowania Unii.

\section{Bibliografia}

Cichocki M. (2012), Zmiana niemieckiego paradygmatu w Europie, „Analizy Natolińskie”, nr 2.

Curtin D., Egeberg M. (2008), Tradition and Innovation: Europe's Accumulated Executive Order, „West European Politics”, vol. 31, nr 4, s. 639-661.

Czachór Z. (2013), Kryzys i zaburzona dynamika Unii Europejskiej, Wydawnictwo Elipsa, Warszawa.

Diez T., Wiener A. (2009), Introducing the Mosaic of Integration Theory, w: European Integration Theory, red. A. Wiener, T. Diez, Oxford University Press, Oxford, s. 1-22.

Finke D. (2009), Challenges to Intergovernmentalism: an Empirical Analysis of EU Treaty Negotiations Since Maastricht, „West European Politics”, vol. 32, nr 3, s. 466-495.

Holzinger K., Schimmelfennig F. (2012), Differentiated Integration in the European Union: Many Concepts, Sparse Theory, Few Data, „Journal of European Public Policy”, vol. 19, nr 2, s. $292-305$.

Joerges C. (2002), 'Deliberative Supranationalism’-Two Defences, „European Law Journal”, vol. 8, nr 1, s. 133-151.

Kölliker A. (2001), Bringing Together or Driving Apart the Union? Towards a Theory of Differentiated Integration, „West European Politics”, vol. 24, nr 4, s. 125-151.

Kunstein T., Wessels W. (2011), Die Europäische Union in der Währungskrise: Eckdaten und Schlüsselentscheidungen, „Integration”, nr 4, s. 308-322.

Menendez A. J. (2011), United They Diverge? From Conflicts of Law to Constitutional Theory? On Christian Joerges'Theory, RECON Online Working Paper 06, ARENA Centre for European Studies.

Moravcsik A. (1995), Liberal Intergovernmentalism and Integration: a Rejoinder, „Journal of Common Market Studies", vol. 33, nr 4, s. 611-628. 
Moravcsik A., Schimmelfennig F. (2009), Liberal Intergovernmentalism, w: European Integration Theory, red. A. Wiener, T. Diez, Oxford University Press, Oxford, s. 67-87.

Neve J.-E. de (2007), The European Onion? How Differentiated Integration is Reshaping the EU, „European Integration”, vol. 29, nr 4, s. 503-521.

Neyer J. (2006), The Deliberative Turn in Integration Theory, „Journal of European Public Policy”, vol. 13 , nr 5, s. 779-791.

Pietraś Z. J. (1998), Decydowanie polityczne, PWN, Warszawa-Kraków.

Pietraś Z. J. (2005), Prawo wspólnotowe i integracja europejska, Wydawnictwo UMCS, Lublin.

Scicluna N. (2012), EU Constitutionalism in Flux: Is the Eurozone Crisis Precipitating Centralisation or Diffusion?, „European Law Journal”, vol. 18, nr 4, s. 489-503.

Skarzyński R. (2012), Podstawowy dylemat politologii: dyscyplina nauki czy potoczna wiedza o społeczeństwie, Wydawnictwo Temida 2, Białystok.

Strzyczkowski F. (2012), Teorie integracji europejskiej w doktrynie amerykańskiej, PWN, Warszawa.

Sudbery I. (2008), Differentiated Integration: a Likely and Acceptable Mechanism to Reconcile Widening and Deepening?, EU - CONSENT, Project No. 513416, Wider Europe, Deeper Integration? Constructing Europe Network.

Tosiek P. (2014), Dynamika kryzysu Unii Europejskiej. Próba analizy systemowej, w: Teoria i praktyka stosunków międzynarodowych. Dziedzictwo intelektualne Profesora Ziemowita Jacka Pietrasia, red. H. Dumała, M. Pietraś, B. Surmacz, A. Ziętek, Wydawnictwo UMCS, Lublin, s. 425-437.

Trondal J. (2010), An Emergent Executive Order, Oxford University Press, Oxford.

Wessels W. (1998), Comitology: Fusion in Action. Politico-Administrative Trends in the EU System, „Journal of European Public Policy”, vol. 5, nr 2, s. 209-234.

Wessels W. (2005), Keynote Article: the Constitutional Treaty - Three Readings from a Fusion Perspective, „Journal of Common Market Studies”, vol. 43, Annual Review, s. 11-36.

Wincott D. (1995), Institutional Interaction and European Integration: towards an Everyday Critique of Liberal Intergovernmentalism, „Journal of Common Market Studies”, vol. 33, nr 4, s. $597-609$.

Zielonka J. (2007), Plurilateral Governance in the Enlarged European Union, „Journal of Common Market Studies", vol. 45, nr 1, s. 187-209.

\section{Streszczenie}

Celem niniejszego artykułu jest przedstawienie nowego koniunktywnego podejścia w badaniach integracji europejskiej: deliberatywnej fuzji międzyrządowej. Bazuje ono na połączeniu liberalnej teorii międzyrządowej, teorii fuzji i teorii deliberatywnego supranacjonalizmu. Główną myślą jest stwierdzenie, że żadna z istniejących koncepcji teoretycznych nie jest w stanie wyjaśnić istoty procesów integracyjnych w ramach Unii Europejskiej. W artykule przedstawiono podstawowe założenia wskazanych teorii (traktowanych jako koncepcje wyjściowe), przeanalizowano główne cechy Unii Europejskiej w czasie kryzysu, a także zaprezentowano podstawowe elementy nowego podejścia. Zaproponowana koncepcja powinna wykazywać przydatność nie tylko w sytuacji kryzysowej, ale także oferować instrumenty analizy integracji europejskiej w okresie pokryzysowym.

Słowa kluczowe: teorie integracji europejskiej, liberalna teoria międzyrządowa, deliberatywny supranacjonalizm, teoria fuzji, kryzys Unii Europejskiej, podejście koniunktywne, integracja zróżnicowana 


\title{
Deliberative intergovernmental fusion - a (post-)crisis approach in European integration research
}

\begin{abstract}
Summary
The purpose of this paper is to present a new conjunctive approach in the research on European integration: deliberative intergovernmental fusion. The concept derives from a merging of liberal intergovernmentalism, fusion theory and deliberative supranationalism. The main idea is based on the view that no existing theoretical concept is able to explain the essence of integration processes in the European Union. This paper presents the principal assumptions of the three theories (treated as starting-point approaches), the main features of the European Union in crisis, as well as basic elements of the new approach. The concept proposed should be useful not only in a crisis situation, but also offer instruments for the analysis of European integration in the post-crisis period.
\end{abstract}

Key words: theories of European integration - liberal intergovernmentalism - deliberative supranationalism - fusion theory - crisis of the European Union - conjunctive approach - differentiated integration 